\title{
Investigasi Sagging Metoda Parabola pada Saluran Transmisi Terhadap Parameter Temperatur pada Saluran 150 Kv pada Gardu Induk Cigereleng
}

\author{
YOSAN AGENG NUGROHO, WALUYO \\ Teknik Elektro Institut Teknologi Nasional Bandung, Indonesia \\ Email: yosan.nugroho@gmail.com
}

Received 5 April 2021 | Revised 10 Mei 2021 | Accepted 26 Juni 2021

\begin{abstract}
ABSTRAK
Andongan adalah bentangan kawat konduktor dari dua ujung titik terendah ditarik garis lurus konduktor tersebut sehingga terbentuk lengkungan kebawah, kekuatan tarik pada andongan berfungsi untuk menahan dari kedua ujung kawat konduktor yang dibentangkan. Besar suatu nilai andongan dapat dilihat dari temperature pada sekeliling saluran transmisi, sehingga siang hari panjang kawat konduktor akan sedikit memanjang diakibatkan sinar matahari, dan sebaliknya malam hari. Untuk mempermudah perhitungan dan analisis andongan dengan menggunakan metoda parabola pada saluran transmisi $150 \mathrm{KV}$, dengan hasil perhitungan secara manual. Andongan dengan metoda parabola pada parameter temperature, temperatur $20^{\circ} \mathrm{C}$ besar andongan 0,0898\%, pada temperature 70 ${ }^{\circ} \mathrm{C}$ tinggi andongan 0,01186\% turun ketika temperature $175{ }^{\circ} \mathrm{C}$ andongan $0,1544 \%$.
\end{abstract}

Kata kunci: Andongan, temperatur, metoda parabola, gardu induk, saluran transmisi $150 \mathrm{KV}$

\begin{abstract}
Sagging is main the stretch of conductor wire from the two ends of the lowest point drawn by a straight line of the conductor so that a downward curve is formed, the tensile strength of sagging serves to hold from both ends of the stretched conductor wire the magnitude of a sagging value can be seen from the temperature around the transmission line, so that during the day the length of the conductor wire will be slightly elongated due to sunlight, and vice versa at night. The facilitate for calculation and analysis of the sagging used the parabolic method on a $150 \mathrm{Kv}$ transmission line, with the results of calculations manually. Sagging with parabolic method at temperature parameters, temperature $20^{\circ} \mathrm{C}$ large sagging of $0.0898 \%$, at a temperature of $70^{\circ} \mathrm{C}$, the sagging height of $0.01186 \%$ decreases when the temperature is $175^{\circ} \mathrm{C}$ sagging $0.1544 \%$.
\end{abstract}

Keywords: sagging, temperature, parabolic method, substation, $150 \mathrm{KV}$ transmission line 


\section{PENDAHULUAN}

Andongan (saging) adalah bentangan kawat konduktor dari dua ujung titik terendah ditarik garis lurus kawat konduktor tersebut sehingga terbentuk lengkungan kebawah, kekuatan tarik pada andongan berfungsi untuk menahan dari kedua ujung kawat konduktor yang dibentangkan, sehingga pada ketinggian tanah yang berbeda-beda bisa menyebabkan tinggi tower dengan tower lainnya akan berbeda (Gardu, 2019).

Berdasarkan uraian analisis pada jurnal dengan hasil penelitian menunjukan setiap bertambahnya temperatur $1^{\circ} \mathrm{C}$ besar nilai andongan akan naik $0,05340 \mathrm{~m}$ atau $0,71060 \%$ sedangkan nilai tension akan berkurang $13,640 \mathrm{~kg}$ atau $0,698390 \%$ (Ihsan, 2017).

Selain hasil penelitian di atas, hal serupa juga dibahas dalam jurnal ini pada hasil nilai andongan yang dihitung sebesar 13,8730 m dari jarak tower $300 \mathrm{~m}$ degan tinggi tower yang sama untuk saluran transmisi tegangan menengah, pada saat tension kawat konduktor kecil akan mengakibatkan nilai kawat konduktor nilainya akan naik (Halim, 2019).

Tujuan dari penulis untuk mencari besar nilai andongan saluran transmisi tegangan menengah pada GI Cigereleng, terhadap parameter temperatur dengan menggunakan simulasi software Microsoft Excel.

\section{METODE PENELITIAN}

\subsection{Metode Penelitian}

Metode penelitian merupakan proses ataupun cara ini bertujuan supaya menentukan tinggi rendahnya suatu andongan terhadap temperature suhu. Metode penelitian dapat dibuat dengan Flowchart. Dan dibawah ini adalah Flowchart pemecahan masalah andongan metoda parabola dengan mengunakan parameter temperatur. Gambar 1 menunjukkan metode penelitian penyusunan jurnal di jelaskan pada Flowchart sebagai berikut.

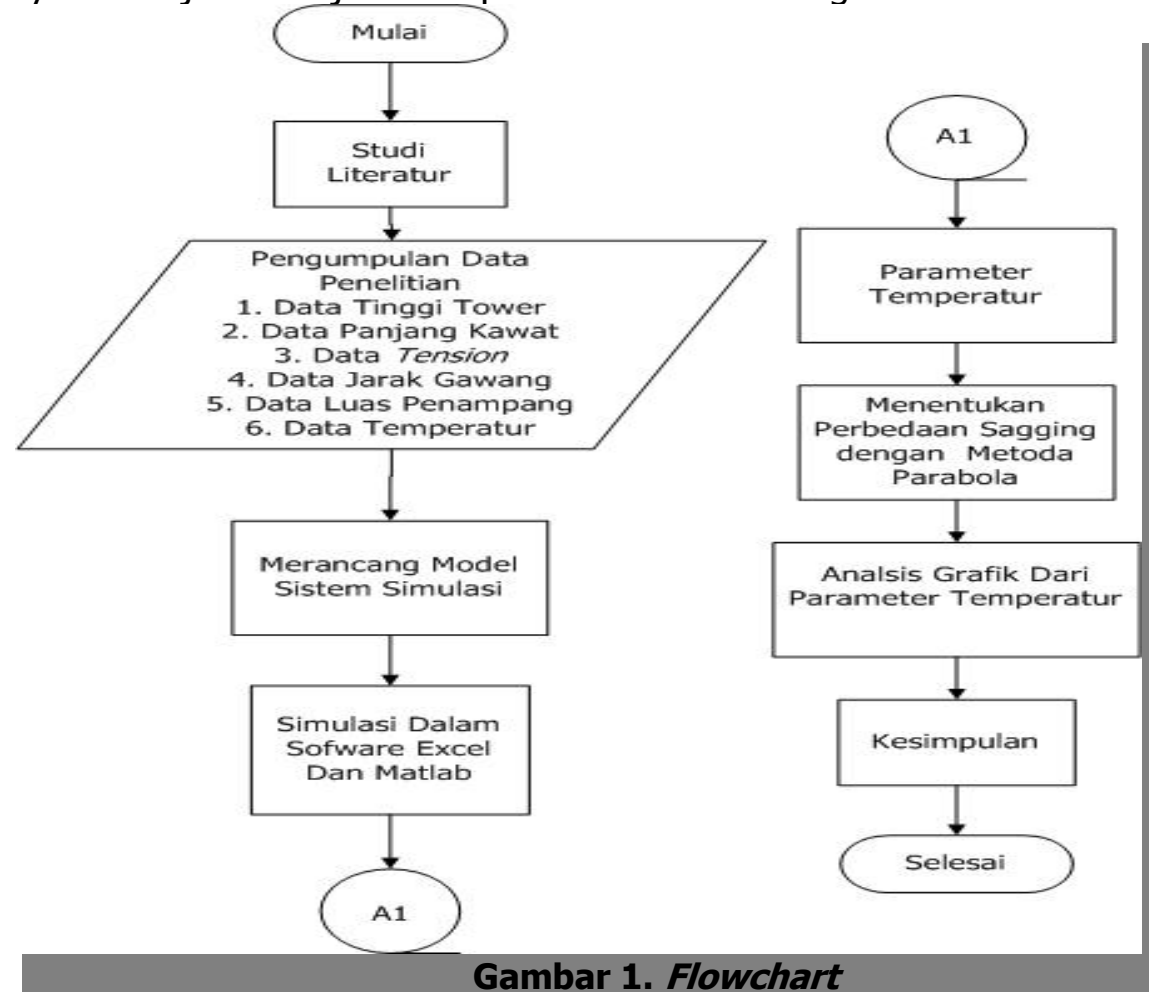


Pada Gambar satu merupakan Flowchart untuk mengetahui besar nilai andongan pada parameter temperatur mengunakan metoda parabola dengan urutan :

Mencari nilai perubahan tarik kawat dengan rumus (Ihsan, 2017).

$$
\begin{aligned}
& \sigma_{\mathrm{t}}^{3}+\mathrm{A} \sigma_{\mathrm{t}}^{3}=\mathrm{B} \\
& \mathrm{A}=\frac{L^{2} Y^{2}}{24 \sigma^{2}} \cdot \mathrm{E}+\alpha \cdot \mathrm{E} \cdot \mathrm{t}-\sigma \\
& \mathrm{B}=\frac{L^{2} Y^{2} E}{24} \\
& \sigma_{\mathrm{t}}=\sqrt[8]{\frac{B}{(1+\mathrm{A})}}
\end{aligned}
$$

Kemudian menentukan nilai tegangan tarik kawat (Ihsan, 2017).

$$
H_{t}=\sigma_{t} \cdot A
$$

Keterangan:

$$
\begin{array}{ll}
\mathrm{a} & =\text { Koefisien pertambahan panjang kawat konduktor }\left(\mathrm{mm}^{2} /{ }^{\circ} \mathrm{C}\right) \\
\mathrm{E} & =\text { Modulus elastisitas kawat konduktor }\left(\mathrm{kN} / \mathrm{mm}^{2}\right) \\
\mathrm{t}_{1} & =\text { Suhu awal kawat konduktor }\left({ }^{\circ} \mathrm{C}\right) \\
\mathrm{t}_{2} & =\text { Suhu akhir kawat konduktor }\left({ }^{\circ} \mathrm{C}\right) \\
\mathrm{S} & =\text { Jarak span }(\mathrm{m}) \\
\mathrm{q} & =\text { Luas penampang kawat konduktor }\left(\mathrm{mm}^{2}\right) \\
\sigma & =\text { Spesifik kawat konduktor tension }\left(\mathrm{kg} / \mathrm{mm}^{2}\right)=\mathrm{T} / \mathrm{q} \\
\mathrm{H} & =\text { tension kawat konduktor }(\mathrm{kg}) \\
\mathrm{Y} & =\text { Nilai secara spesifik kawat konduktor }\left(\mathrm{kg} / \mathrm{m} / \mathrm{mm}^{2}\right)=\mathrm{w} / \mathrm{q} \\
\mathrm{W} & =\text { Nilai kawat konduktor }(\mathrm{kg} / \mathrm{m}) \\
\mathrm{ot} & =\text { Spesifik tension kawat konduktor pada saat } \mathrm{t}^{\circ} \mathrm{C}\left(\mathrm{kg} / \mathrm{mm}^{2}\right) \\
\mathrm{A}, \mathrm{B} & =\text { variabel kedua titik } \\
\mathrm{H}_{\mathrm{t}} & =\text { Tension kawat konduktor pada saat } \mathrm{t}^{\circ} \mathrm{C}\left(\mathrm{kg} / \mathrm{mm}^{2}\right)
\end{array}
$$

Mencari nilai sagging dengan metoda parabola (Elektro, 2011).

$$
\begin{aligned}
& \mathrm{d}=\frac{w s^{2}}{8 \cdot \mathrm{t}} \\
& \mathrm{L}=\frac{2 H}{\mathrm{~W}} \sinh \frac{w s^{2}}{2 H}
\end{aligned}
$$

Keterangan:

$\mathrm{L} \quad=$ Panjang kawat $(\mathrm{m})$

$\mathrm{d}=$ Besar nilai andongan $(\mathrm{m})$ 


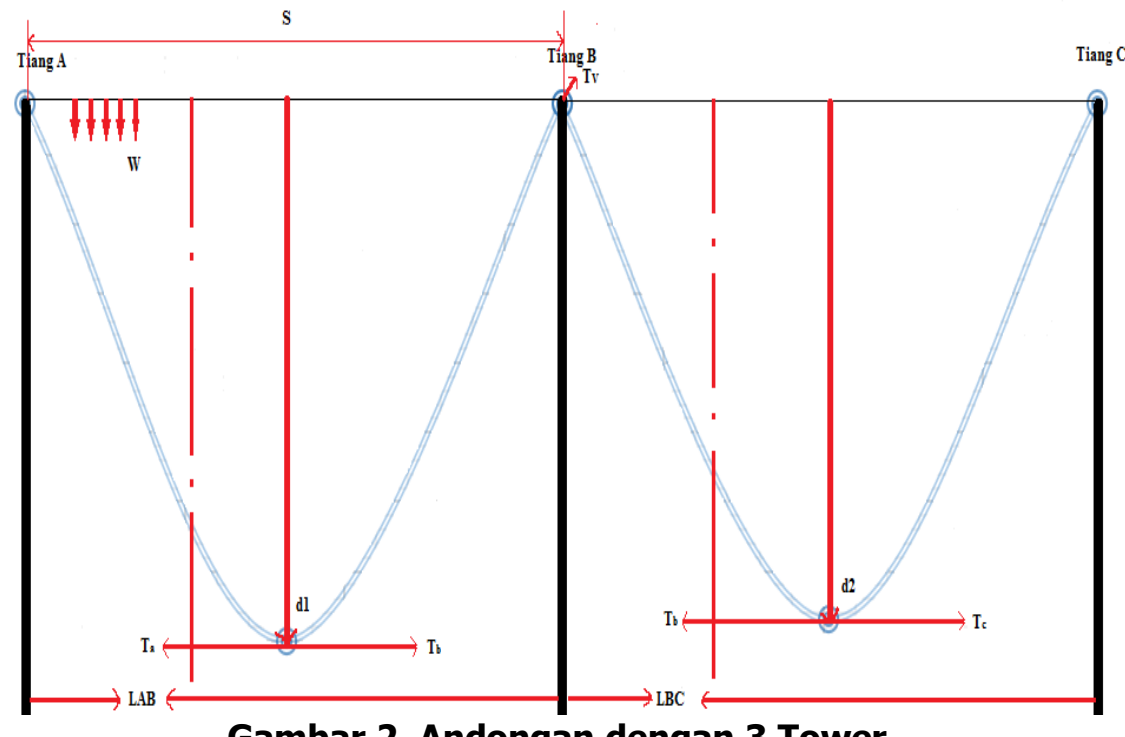

Gambar 2. Andongan dengan 3 Tower

Gambar 2 menunjukan tinggi rendahnya suatu andongan dengan tiga tower, pembanding parameter terhadap temperatur pada saat temperatur $20^{\circ} \mathrm{C}$ pengaruh temperatur terhadap andongan.

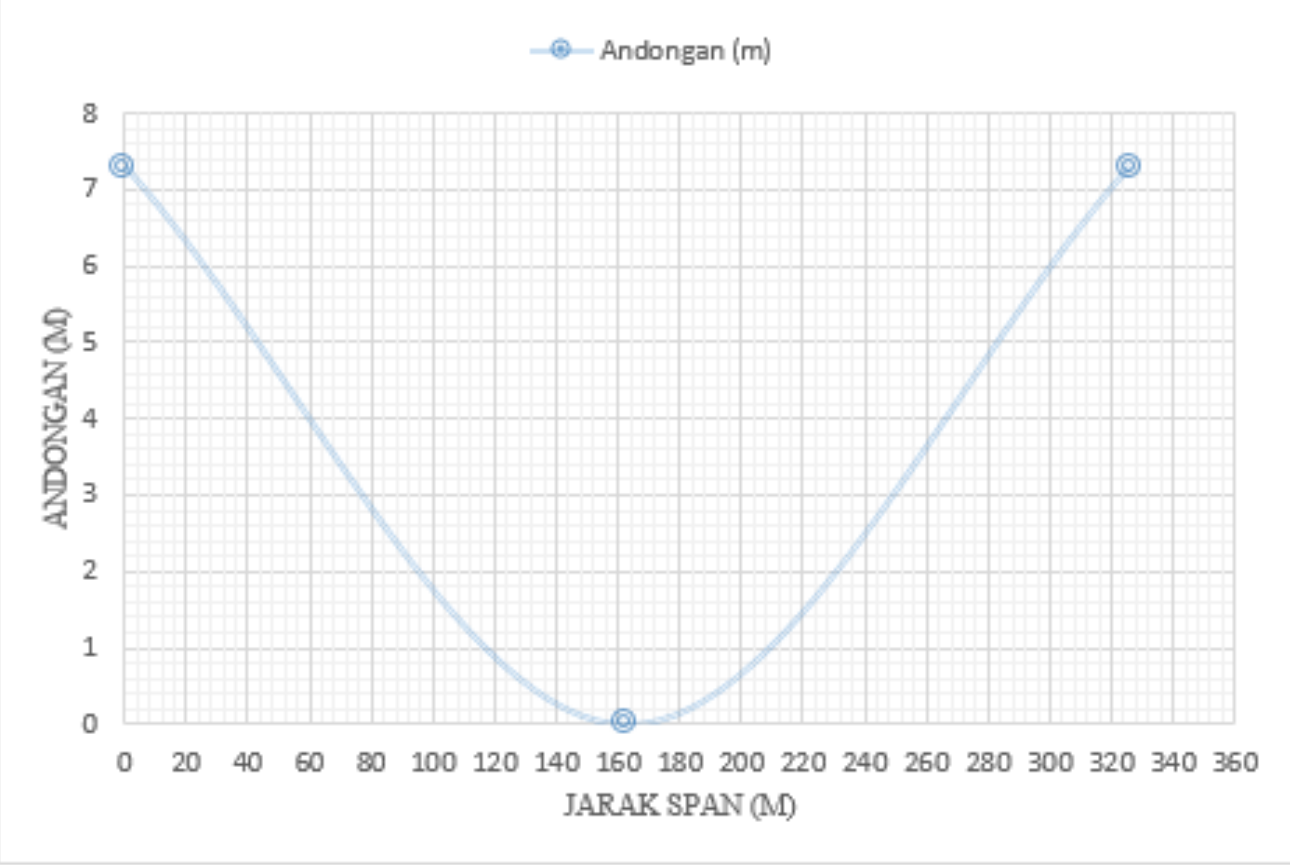

Gambar 3. Simulasi Menggunakan Sofware Microsoft Excel

Gambar 3 diatas merupakan hasil dari perhitungan metoda parabola dengan parameter temperature.

\subsection{Pengaruh Internal terhadap Andongan dan Tegangan Tarik}

Kawat penghantar atau kawat konduktor pada umumnya tahan terhadap perubahan suhu berdampak pada arus yang melaluinya dan tahan pada kekuatan tekanan tarik yang terjadi pada pembebanan mekanik maupun elektrik. Pada saat kawat konduktor terdapat 
perubahan arus ialah pengaruh yang terdapat di dalamnya yang menyebabkan kenaikan besar nilai andongan (sagging) dan Tension (tegangan tarik) (Lastya, 2016).

\subsection{Saluran Transmisi Energi Listrik}

Saluran transmisi energi listrik yaitu pada saat pengiriman energi listrik dari PLTA (Power Plant) sampai saluran transmisi bisa disalurkan ke pada pemukiman penduduk atau kepabrik melalui kawat penghantar (Tambunan, 2019).

Di masa modern pada saat ini membutuhkan energy electricity sudah jadi keutamaan dari kota ataupun desa, nyaris seluruh perlengkapan hidup tiap hari memerlukan energy electricity. Sebab sadar paling tidak seluruh universal gimana electricity menjalankan serta saluran energy electricity dari sumbernya ke penerima. PLN merupakan salah satunya industri yang bergerak di bidang distribusi tenaga listrik (Aribowo, 2018).

Pada sistem tenaga listrik, jarak antara pembangkit dengan beban yang lumayan jauh, sehingga memunculkan terdapatnya penyusutan kualitas tegangan yang disebabkan oleh rugi- rugi pada jaringan. Sehingga diperlukan sesuatu perlengkapan untuk membetulkan mutu tegangan serta diletakkan pada saluran yang terdapat drop tegangan (IImiah \& Teknik, 2016).

\subsection{Tahap Konstruksi SUTT $150 \mathrm{Kv}$}

Sesi konstruksi dalam pembangunan SUTT 150 Kv meliputi: (Wantouw, 2014)

a. Perlengkapan serta bahan, proses pengangkutan bahan- bahan/ material yang dibutuhkan buat pembangunan pondasi tapak tower, besi-baja tower, kawat penghantar, insulator, serta lain- lain.

b. Pembuatan pondasi menara

c. Pendirian tower, aktivitas pendirian tower ini secara keseluruhan meratakan tanah. Meratakan tanah dicoba memakai perlengkapan yang lebih canggih apabila dibutuhkan.

d. Pada saat penarikan kawat konduktor(Stringing) dicoba menggunakan perlengkapan pulling winches machine.

e. Saluran tenaga listrik, pekerjaan ini biasa diucap menggunakan sebutan energize.

\subsection{Kawat Penghantar}

Pemakaian tipe konduktor ialah salah satu metode buat merendahkan rugi- rugi yang terdapat dalam saluran. Kawat penghantar tipe ACCC diketahui dapat unggulkan pada saat mengirimkan energi listrik dibandingkan tipe konduktor Aluminium Conductor Steel Reinforced (Handayani, 2019).

Kawat penghantar aluminium, terdiri dari bermacam tipe ialah: (Pengaruh, 2020)

a. AAC ialah kawat konduktor yang semuanya dibuat dari bahan aluminium, biasanya sering disebut dengan Al/-Aluminium Conductor.

b. AAAC ialah kawat konduktor yang semuanya dibuat dari bahan kombinasi aluminium, biasanya sering disebut dengan All-Aluminium Alloy Conductor.

c. ACSR ialah kawat konduktor aluminium yang di dalamnya berisikan kawat baja, biasanya sering disebut dengan Aluminium Conductor Steel Reinforced.

d. ACAR ialah kawat konduktor aluminium yang diperkuat dengan logan kombinasi, biasanya sering disebut dengan Aluminium Conductor Alloy Reinforced.

Kawat konduktor pada saluran transmisi digunakan pada jarak 2 tower, berupa sesuatu line horizontal, maka hendak terlihat sesuatu lengkungan ataupun sagging. Sebab energy electricity ialah Tension besar, hingga kawat konduktor yang bertegangan bisa memunculkan dielektrik. dielektrik sesuatu saluran transmisi disebabkan terdapat beda potensial pada jarak 
konduktor, serta bumi bisa pengaruhi kapasitansi saluran transmisi sebab kedatangan earth itu akan mengganti medan energi listrik (Gardu, 2019).

Konduktor HTLS ialah teknologi yang dibesarkan buat penuhi kebutuhan energi listrik. Konduktor tipe ini memiliki temperatur yang sangat besar apabila dibanding dengan konduktor yang konvesional. Sehingga dengan memiliki titik temperatur yang besar hingga kapasitas hantar arus terus menjadi besar. Sebab arus yang lewat suatu konduktor memiliki batasan ambang temperatur yang ada pada konduktor. Tidak hanya itu pula konduktor HTLS ini memiliki konduktivitas dan kokoh tariknya yang lebih baik dibanding dengan konduktor yang konvesional (Desprianto, 2015).

\subsection{Pengaruh Tekanan Angin Terhadap Andongan}

Tekanan angin akan mempengaruhi berat spesifik kawat. Berat sendiri kawat bekerja vertikal sedang tekanan angin dianggap seluruhnya bekerja horizontal. Jumlah vektoris kedua gaya ini menjadi berat total spesifik kawat. Besar perubahan kecepatan angin tidak berpengaruh secara signifikan terhadap nilai tegangan tarik, andongan, dan panjang kawat konduktor (Prasetyono, 2015).

\subsection{GI (Gardu Induk)}

GI (Gardu Induk) ialah tempat pengiriman transmisi energi listrik dari suatu PLTA (power plant) kepada pengguna untuk dikirimkan ke penduduk ataupun pabrik, pada GI (Gardu Induk) juga tempat pengiriman secara totalitas. GI (Gardu Induk) yang dibentuk ialah gardu induk konvensional dimana sebagian besar (Parinduri, 2016).

GI (Gardu Induk) ialah komponen penyaluran energi listrik memegang peranan yang sangat penting karena merupakan penghubung pelayanan tenaga listrik ke konsumen. Fungsi Gardu Induk adalah : (Gunawan, 2013)

a. Menerima dan menyalurkan tenaga listrik sesuai dengan kebutuhan pada tegangan tertentu dengan aman dan dapat digunakan

b. Saluran daya ke gardu induk lainnya dan gardu - gardu distribusi dilewati saluran tegangan 60 sampai $150 \mathrm{Kv}$.

Sistem Data Monitoring Gardu Induk serta Gardu Distribusi PLN sesuatu wujud sistem data yang berperan buat memantau kondisi Gardu Induk serta Gardu Distribusi PLN dengan menggunakan jaringan internet. Data hasil pemantauan hendak ditampilkan pada suatu web. Sistem data monitoring gardu induk dibutuhkan sebab sistem SCADA yang terdapat tidak menjangkau gardu distribusi. Sistem data ini digunakan oleh operator gardu induk dan Unit Pembagi Beban( UPB) buat mengenali kondisi trafo dan beban energi listrik. Data beban energi listrik digunakan apabila beban meningkat hingga frekwensinya hendak turun sehingga PLN wajib menaikkan energi demikian pula kebalikannya apabila beban turun hingga PLN hendak kurangi energi yang terdapat. Data yang ditampilkan pada web tersebut berbentuk tegangan, arus serta temperatur trafo Gardu Induk serta Gardu Distribusi (Iskandar, 2011). 


\section{DATA,HASIL DAN ANALISIS}

\subsection{Data}

Tabel 1 menunjukkan data dilapangan saluran transmisi tegangan menengah pada GI Cigereleng

Tabel 1. Data Penghantar SUTT 150 kv Cigereleng - Bandung Selatan

\begin{tabular}{|c|l|c|c|}
\hline NO & \multicolumn{1}{|c|}{ KATEGORI } & NILAI & SATUAN \\
\hline 1 & Panjang Rute & 13,26 & $\mathrm{~km}$ \\
\hline 2 & Panjang Sirkit & 26,52 & $\mathrm{kms}$ \\
\hline 3 & Jenis Konduktor & $2 \times$ ACCC LISBON & - \\
\hline 4 & Hambatan Jenis Almunium $(\rho)$ & $2,82 \times 10^{-8}$ & $\Omega \mathrm{m}$ \\
\hline 5 & Diameter Konduktor $(\mathrm{d})$ & 22,4 & $\mathrm{~mm}$ \\
\hline 6 & Kekuatan Tarik $(\mathrm{H})$ & 2000 & $\mathrm{kN}$ \\
\hline 7 & Gaya Tarik horizontal pada penghatar $(\mathrm{t})$ & 10,210 & $\mathrm{Kg}$ \\
\hline 8 & Modulus Elastisitas (E) & 6300 & $\mathrm{~kg} / \mathrm{mm}^{2}$ \\
\hline 9 & Luas Penampang Konduktor $(\mathrm{A})$ & 240 & $\mathrm{~mm}$ \\
\hline 10 & Tegangan Kawat Spesifik $(\sigma)$ & 5,58 & $\mathrm{~kg} / \mathrm{mm}^{2}$ \\
\hline 12 & Berat Kawat Spesifik $(Y)$ & $2,67 \times 10^{-3}$ & $\mathrm{~kg} / \mathrm{m}^{2}$ \\
\hline 13 & Jarak Gawang Dilapangan $(\mathrm{s})$ & 326 & $\mathrm{M}$ \\
\hline 15 & Koefisien Pertambahan Jarak $(\alpha)$ & $23,0 \times 10^{-6}$ & ${ }^{\circ} \mathrm{C}^{-1}$ \\
\hline 16 & Berat Konduktor & 1,11 & $\mathrm{~kg} / \mathrm{m}$ \\
\hline 17 & Temperatur Operasi Maksimum & 75 & ${ }^{\circ} \mathrm{C}$ \\
\hline 18 & Temperatur Operasi Minimum & 20 & ${ }^{\circ} \mathrm{C}$ \\
\hline 19 & Jumlah Menara Transmisi & 41 & $\mathrm{Tower}$ \\
\hline 20 & Tinggi Menara & 38 & $\mathrm{M}$ \\
\hline
\end{tabular}

Pada Table 1 merupakan data lapangan disaluran transmisi tegangan menengah pada GI Cigereleng.

\subsection{Hasil Pengolahan Data}

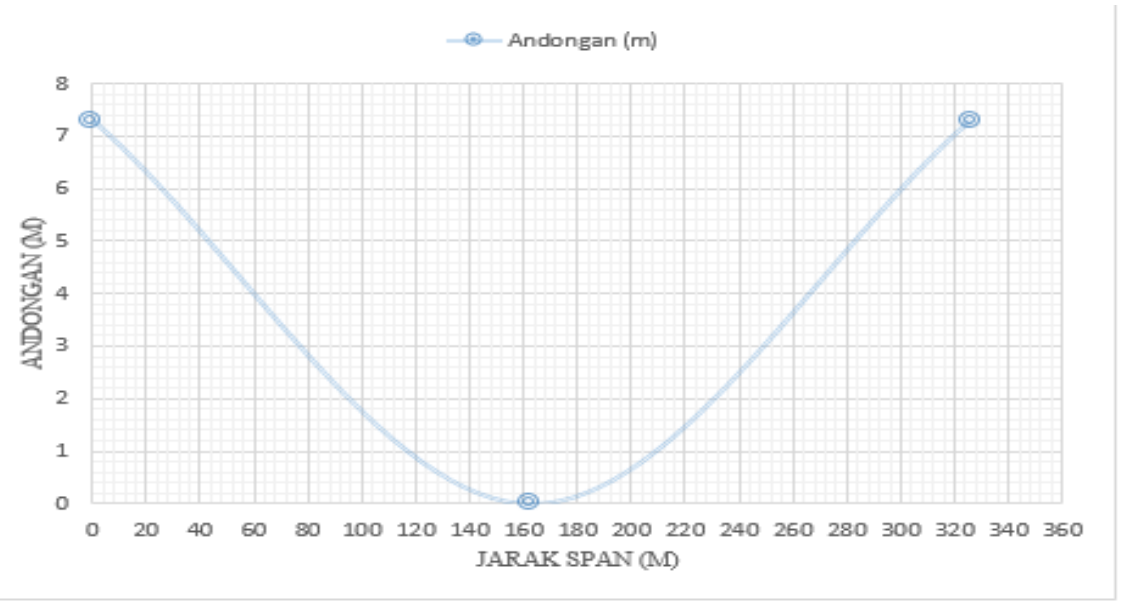

Gambar 4. Andongan Menggunkan Metoda Parabola 
Gambar 4 merupakan hasil perhitungan dari data PLN yang belum terpengaruh oleh parameter temperatur, gambar diatas menunjukkan tinggi andongan sebesar 7,3 meter, panjang konduktor 335,65 meter, dan jarak Span 326 sedangkan kekuatan tarik kawat sebesar 2005,18 kN.

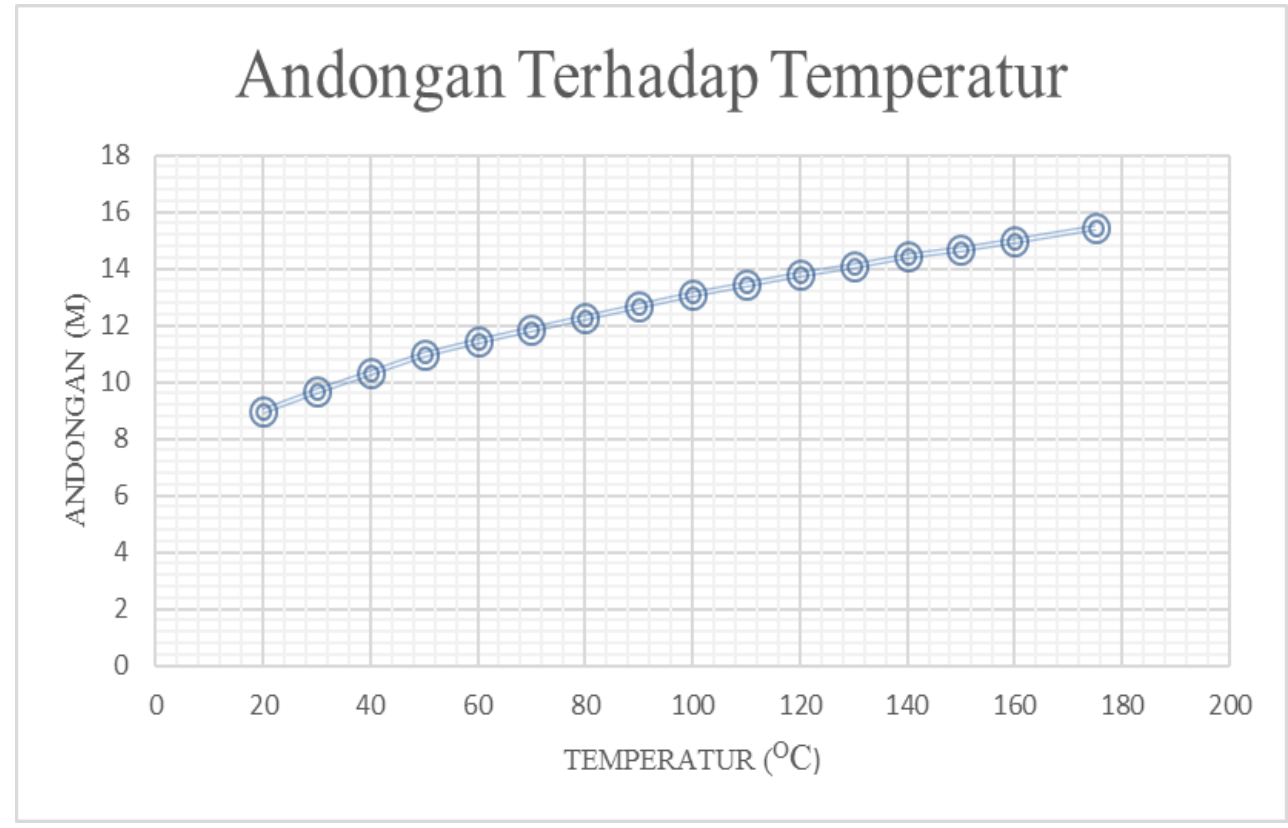

Gambar 5. Andongan Terhadap Temperatur

Gambar 5 diatas merupakan andongan terhadap temperatur pada saat parameter temperatur menunjukkan tinggi andongannya besar maka temperaturnya ikut naik dikarenakan konduktor yang memuai akibat tingginya temperatur dan sebaliknya jika temperatur kecil maka andonganya kecil, pada temperatur $20^{\circ} \mathrm{C}$ besar andongan $8,98 \mathrm{~m}$, pada saat temperatur $30^{\circ} \mathrm{C}$ besar andongan $9,69 \mathrm{~m}$, pada saat temperatur $40{ }^{\circ} \mathrm{C}$ besar andongan $10,34 \mathrm{~m}$, pada saat temperatur $50^{\circ} \mathrm{C}$ besar andongan $10,89 \mathrm{~m}$, pada saat temperatur $60^{\circ} \mathrm{C}$ besar andongan $11,42 \mathrm{~m}$, pada saat temperatur $70^{\circ} \mathrm{C}$ besar andongan $11,86 \mathrm{~m}$, pada saat temperatur $80^{\circ} \mathrm{C}$ besar andongan $12,28 \mathrm{~m}$, pada saat temperatur 90 ${ }^{\circ} \mathrm{C}$ besar andongan $12,69 \mathrm{~m}$, pada saat temperatur $100^{\circ} \mathrm{C}$ besar andongan $13,07 \mathrm{~m}$, pada saat temperatur $110{ }^{\circ} \mathrm{C}$ besar andongan $13,47 \mathrm{~m}$, pada saat temperatur $120^{\circ} \mathrm{C}$ besar andongan $13,77 \mathrm{~m}$, pada saat temperatur $130^{\circ} \mathrm{C}$ besar andongan $14,09 \mathrm{~m}$, pada saat temperatur $140{ }^{\circ} \mathrm{C}$ besar andongan $14,42 \mathrm{~m}$, pada saat temperatur $150{ }^{\circ} \mathrm{C}$ besar andongan $14,69 \mathrm{~m}$, pada saat temperatur $160{ }^{\circ} \mathrm{C}$ besar andongan $14,98 \mathrm{~m}$,dan temperatur $175^{\circ} \mathrm{C}$ besar andongan $15,44 \mathrm{~m}$. 


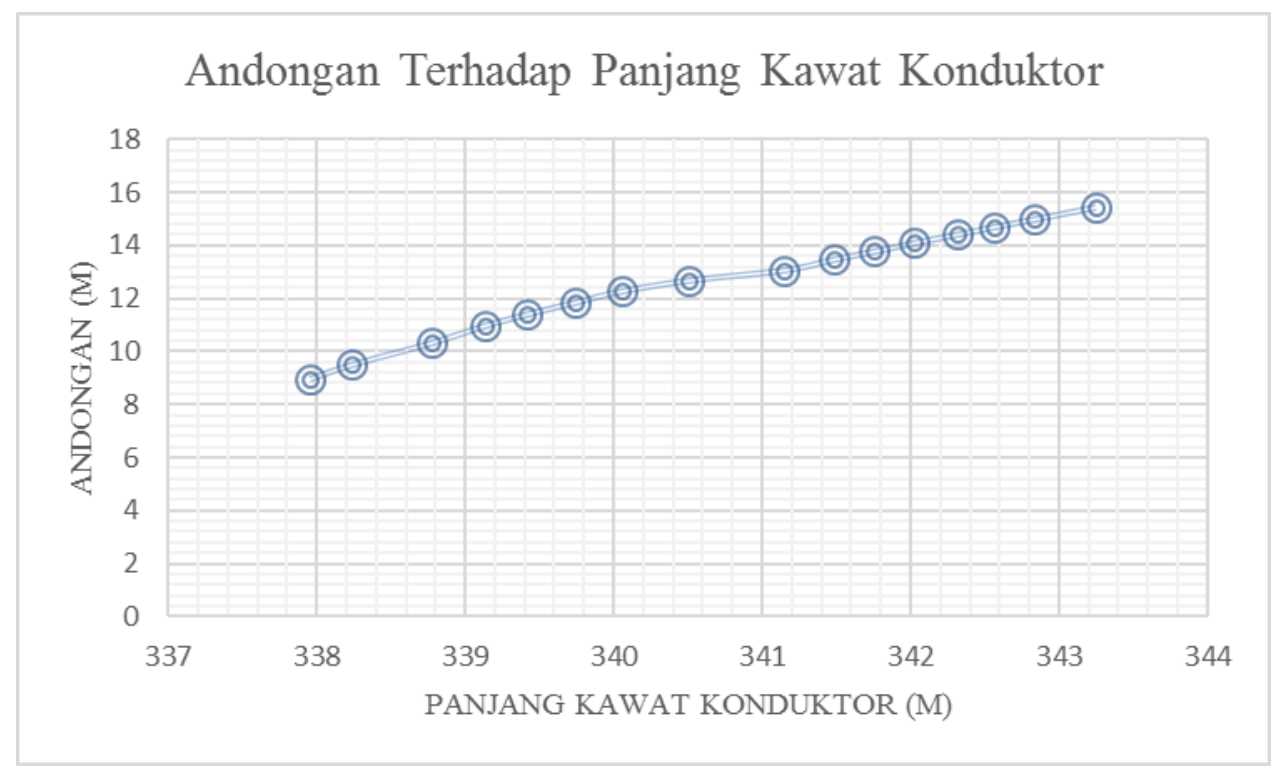

Gambar 6. Andongan Terhadap Panjang Kawat Konduktor

Gambar 6 diatas merupakan andongan terhadap panjang kawat pada saat parameter temperatur menunjukkan andongan kecil maka panjang kawat atau konduktornya kecil jika andongannya tinggi maka panjang kawat atau konduktornya juga ikut naik, pada temperatur $20{ }^{\circ} \mathrm{C}$ panjang kawat konduktor $337,86 \mathrm{~m}$, pada saat temperatur $30{ }^{\circ} \mathrm{C}$ panjang kawat konduktor $338,23 \mathrm{~m}$, pada saat temperatur $40{ }^{\circ} \mathrm{C}$ panjang kawat konduktor $338,77 \mathrm{~m}$, pada saat temperatur $50{ }^{\circ} \mathrm{C}$ panjang kawat konduktor $339,13 \mathrm{~m}$, pada saat temperatur $60^{\circ} \mathrm{C}$ panjang kawat konduktor $339,42 \mathrm{~m}$, pada saat temperatur 70 ${ }^{\circ} \mathrm{C}$ panjang kawat konduktor $339,74 \mathrm{~m}$, pada saat temperatur $80{ }^{\circ} \mathrm{C}$ panjang kawat konduktor $340,51 \mathrm{~m}$, pada saat temperatur $90{ }^{\circ} \mathrm{C}$ panjang kawat konduktor $341,15 \mathrm{~m}$, pada saat temperatur $100^{\circ} \mathrm{C}$ panjang kawat konduktor $341,48 \mathrm{~m}$, pada saat temperatur $110{ }^{\circ} \mathrm{C}$ panjang kawat konduktor $341,75 \mathrm{~m}$, pada saat temperatur $120^{\circ} \mathrm{C}$ panjang kawat konduktor $342,02 \mathrm{~m}$, pada saat temperatur $130{ }^{\circ} \mathrm{C}$ panjang kawat konduktor $342,32 \mathrm{~m}$, pada saat temperatur $140^{\circ} \mathrm{C}$ panjang kawat konduktor $342,32 \mathrm{~m}$, pada saat temperatur $150{ }^{\circ} \mathrm{C}$ panjang kawat konduktor $342,56 \mathrm{~m}$, pada saat temperatur $160^{\circ} \mathrm{C}$ panjang kawat konduktor $342,83 \mathrm{~m}$, dan temperatur $175^{\circ} \mathrm{C}$ panjang kawat konduktor $343,25 \mathrm{~m}$.

\subsection{Analisis Data}

Pada hasil Pada Parameter temperature, dari temperature $20{ }^{\circ} \mathrm{C}$ besar nilai andongan $0,0898 \%$ turun ketika temperature $175{ }^{\circ} \mathrm{C}$ andongan $0,1544 \%$, sedangkan pada andongan terhadap panjang konduktor temperature $20{ }^{\circ} \mathrm{C}$ panjang kawat konduktor $3,3786 \%$ turun ketika temperature $175^{\circ} \mathrm{C}$ panjang kawat konduktor $3,4325 \%$, pada saat bisa disimpulkan jika temperaturnya semakin panas maka andongannya akan rendah jika, temperature dingin makan andongan akan naik seperti pada siang hari andongan akan tinggi atau kawat konduktornya lebih kebawah dikarenakan panas matahari dan sebaliknya andongan akan naik ketika malam hari. 


\section{KESIMPULAN}

Berdasarkan dari hasil perhitungan dan analisis bisa diambil kesimpulan ialah:

1. Metoda parabola kebanyakan sagging konduktor dan perhitungan tegangan secara teoritis didasarkan pada rentang jarak span sederhana dari konduktor yang dihitung pada ketinggian yang sama.

2. Pada saat metoda parabola panjang konduktor akan berubah dengan perubahan suhu sesuai dengan parameter.

3. Nilai yang di dapat pada parameter temperatur $20^{\circ} \mathrm{C}$ dengan andongan sebesar 0,0898\%.

4. Nilai Nilai yang di dapat pada parameter temperatur $175^{\circ} \mathrm{C}$ dengan andongan sebesar 0,1544\%.

5. Nilai yang di dapat pada parameter temperatur $20{ }^{\circ} \mathrm{C}$ dengan panjang kawat konduktor 3,3786\%.

6. Nilai Nilai yang di dapat pada parameter temperatur $175{ }^{\circ} \mathrm{C}$ dengan panjang kawat konduktor 3,4325\%.

\section{UCAPAN TERIMA KASIH}

Penulis sangat berterima kasih sebesar-besarnya pada PT Indonesi Power Gardu Induk Cigereleng yang sudah membagikan izin penulis buat melaksanakan penilitian.

\section{DAFTAR RUJUKAN}

Aribowo, D., Permata, E., Ekawati, R., Hamid, M. A., Fatkhurrohman, M., Dharmawan, I., \& Bahtiar, K. (2018). Analisis Hasil Uji PMT 150kV Pada Gardu Induk Cilegon Baru BAY KS 1. 59-65.

Desprianto, R. Y., Prasetyono, S., Setiawan, D. K., Elektro, J. T., Teknik, F., Unej, U. J., \& Kalimantan, J. (2015). Studi Perencanaan Upgrade Transmisi Tegangan Tinggi $150 \mathrm{kV}$ Perak-Ujung Menggunakan Konduktor HTLS ( High Temeprature-Low Sag ).

Elektro, J. T., Teknik, F., Diponegoro, U., \& Pendahuluan, I. (n.d.). $V=A=d=H \cdot w L W \cdot$ $2 H 8 H 2 H w L \sinh w 2 H \Delta t I=.1-7$.

Gardu, D., Keramasan, I., \& Gardu, K. E. (2019). Pengaruh Andongan Terhadap Kapasitansi Ke Tanah Pada Saluran Transmisi 150 Kv Induk Mariana. 4(1), 275-289.

Gunawan, S. M., Santosa, J., Elektro, J. T., Petra, U. K., Siwalankerto, J., \& Induk, A. G. (2013). Analisa Perancangan Gardu Induk Sistem Outdoor 150 kV di Tallasa, Kabupaten Takalar, Sulawesi Selatan. 1(1), 37-42.

Halim, A., Andongan, M., Saluran, K., Kv, T., \& Halim, A. (n.d.). Menghitung Andongan Kawat Saluran Transmisi 150 Kv. 1099, 144-149.

Handayani, O., Darmana, T., \& Widyastuti, C. (2019). Energi dan Kelistrikan: Jurnal IImiah 
Analisis Perbandingan Efisiensi Penyaluran Listrik Antara Penghantar ACSR dan ACCC pada Sistem Transmisi 150kV Energi dan Kelistrikan: Jurnal Ilmiah. 11(1), 37-45.

Ihsan, M., Sara, I. D., \& Lubis, R. S. (2017). Pengaruh Suhu dan Angin Terhadap Andongan dan Kekuatan Tarik Konduktor Jenis ACCC Lisbon. 2(3), 42-50.

Ilmiah, J., \& Teknik, P. (2016). Analisis kerugian daya pada saluran transmisi tegangan ekstra tinggi $500 \mathrm{kv}$ unit pelayanan transmisi cilegon baru - cibinong.

Iskandar, D. (2011). Sistem informasi gardu induk dan gardu distribusi pln. 2011(semnasIF), 26-31.

Lastya, H. A., Teknik, P., Fakultas, E., \& Uin, K. (n.d.). Analisa Pengaruh Eksternal Dan Internal Terhadap Andongan Dan Tegangan Tarik Pada Saluran Transmisi 150 KV. 135148.

Parinduri, L. (2016). Pembangunan Gardu Induk 150 KV di Desa Parbaba Dolok Kecamatan Pangururan Kabupaten Samosir. 1099, 13-18.

Pengaruh, A., Dan, A., Pada, T., Penghantar, K., Andongan, T., Tarik, T., Saluran, P., Tegangan, U., Studi, P., Elektro, T., Teknik, F., Muhammadiyah, U., \& Utara, S. (2020). Tugas akhir.

Prasetyono, S. (n.d.). Pengaruh Kecepatan Angin pada Karakteristik Performansi Konduktor SUTET.

Tambunan, J. M., \& Mulyono, H. (2019). Reposisi dan Penggantian Menara Transmisi 150 kV. 21(2), 87-99.

Wantouw, F., Mandagi, R. J. M., Pascasarjana, D., Sipil, T., \& Sam, U. (2014). Manajemen Resiko Proyek Pembangunan Saluran Udara Tegangan Tinggi ( SUTT) $150 \mathrm{k} \mathrm{V}$ LOPANA-TELING. 4(4), 239-256. 